plates coated with a thin layer of platinum which can blot gels up to $17 \mathrm{~cm}$ long. The GENIE also features an insertable loading tray that the company says will help achieve bubble-free loading. Idea's

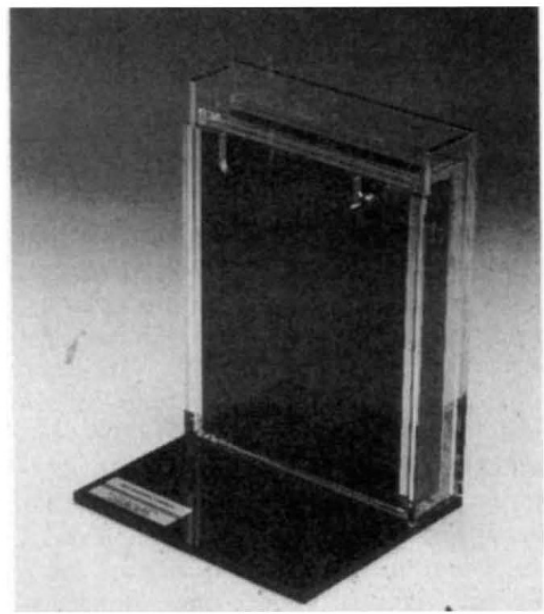

The uniform field theory comes to electrophoresis.

machine requires less than one litre of buffer. Another version is available for gels up to $32 \mathrm{~cm}$ long.

Becton-Dickinson has recently released a new monoclonal antibody for $B$ cell studies (Reader Service No. 115). The antibody, called Anti-Leu-16, reacts with an antigen found on human B cells in peripheral blood, tonsil and lymph node tis-

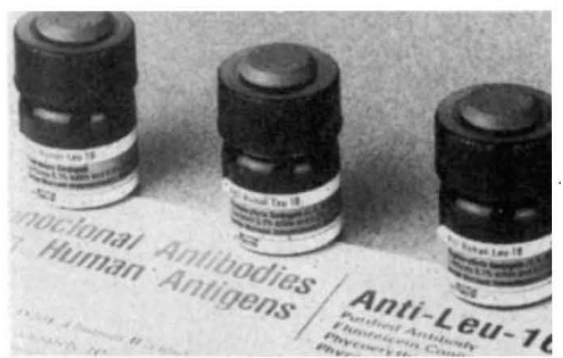

Becton-Dickinson's tool for trailing B cells.

sue. The antigen appears on approximately 10 per cent of peripheral blood lymphocytes, according to B-D. The company also says Anti-Leu-16 will not react with T cells or granulocytes and exhibits marginal reaction with monocytes. Available in purified form or as a fluorescein or phycoerythrin conjugate, the antibody can be used for B cell enumeration in peripheral blood, B cell isolation and studies of B cell neoplasms and activation.

\section{Erratum: streptavidin pricing}

A review published in the 29 May issue of Nature (Vol. 321, p. 543) gave an incorrect price for Porton Products Ltd's streptavidin. In the United Kingdom, the chemical costs $£ 5$ per $0.5 \mathrm{mg}$, not $100 \mathrm{mg}$ as previously stated. Porton Products sells streptavidin in $100 \mathrm{mg}$ quantities for $£ 1.000$.
The latest version of Bio-Rad's MAPS (Monoclonal Antibody Purification System) kit has been designed specifically

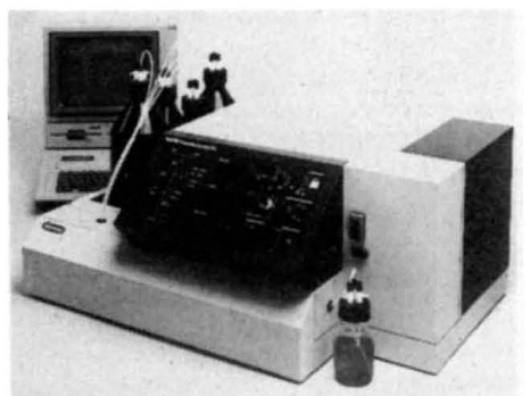

MAPS dedicated to particular purifications.

for the purification of mouse IgG from ascites fluid (Reader Service No. 116). The kit, called Affi-Gel Protein A MAPS II, consists of protein A with MAPS buffers optimized for binding, elution and regeneration. Bio-Rad says the binding buffer increases the protein A-agarose capacity for $\operatorname{IgG}$ from less than $1 \mathrm{mg}$ per $\mathrm{ml}$ to 6 to $8 \mathrm{mg}$ per $\mathrm{ml}$ of gel. The elution buffer, the company claims, gives quantitative elution of bound $\mathrm{IgG}$, and the regeneration buffer provid's for up to 12 cycles. The entire $\mathrm{kii}$ contains the materials necessary to purify $500 \mathrm{mg}$ of murine antibody.

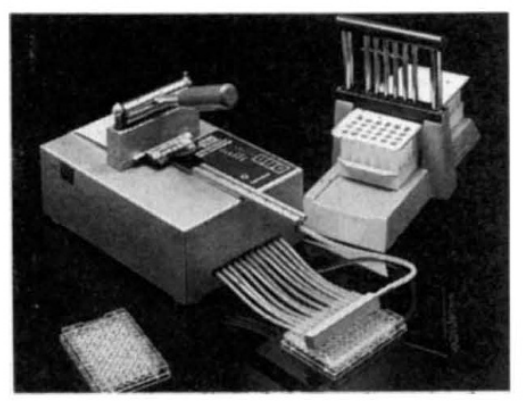

Applications for Skatron's new harvester keep growing.

Skatron is promoting a new cell harvester as an aid in receptor binding studies (Reader Service No. 117). The company describes a procedure that is intended to reduce the time and costs involved in filtration and reduce the levels of nonspecific binding. With Skatron's instrument, twelve incubation samples can be simultaneously filtered under reduced pressure. Another component, the Filterpunch, transfers the filter disks six at a time to scintillation vials. Skatron's cell harvester can also be employed in studies of HTLV-III/LAV infections.

These notes are compiled by Karen Wright from information provided by the manufacturers. To obtain further details about these products, use the reader service card bound inside the journal.

Prices quoted are sometimes nominal and apply only within the country indicated.
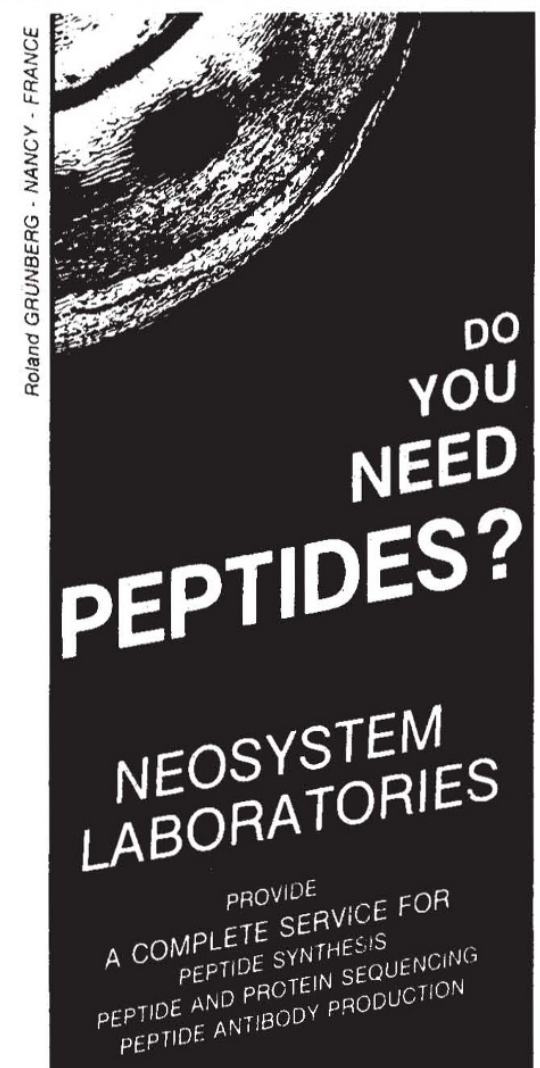

WE PROVIDE ALSO

WE PROVEARCH SERVEMIC

CONTRACT RESEL AND ACAR

TO INDUSTRIATTUTIONS

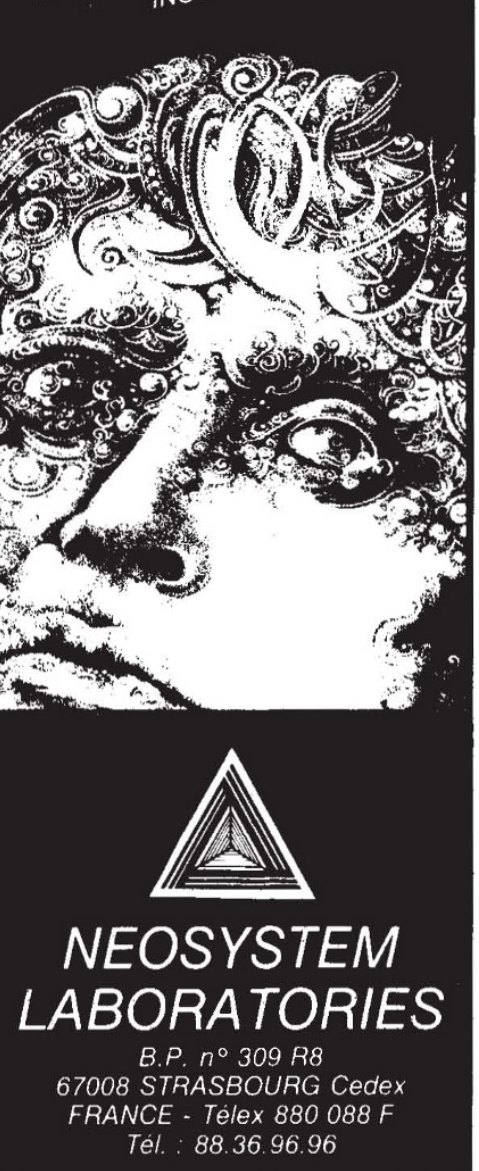

